\title{
8. The representation of female athletes in online images of successive Olympic Games
}

\begin{abstract}
Photographs tell stories. They are 'so much a part of our daily lives we rarely think about how they influence us and what that influence is'. Yet photographs, like other media images, can be used to legitimate the interests of hegemonic groups seeking to shape consensus or consent to existing social arrangements (Duncan, 1990, p. 22). A content analysis of 2004 Olympic Games coverage on the website of Australia's national public broadcaster, $\mathrm{ABC}$ News Online, shows that images of female athletes outnumbered those of male athletes. However, in line with results from analysis of 2000 Olympics coverage on News Online, women competing in team sports received little recognition and females were frequently depicted as passive subjects rather than active competitors. Such under-representation for team players and stereotypical portrayals of sportswomen on News Online may instill in its news audiences the belief that women's sports are less powerful, less interesting and thus separate and different from men's sports.
\end{abstract}

DIANNE JONES

University of Southern Queensland

$\mathrm{F}$

OR DECADES journalists have been accused of telling only half the story in their coverage of sport. A 2005 survey of the international sports press, including Australia, shows few differences in the focus of sports pages from 37 newspapers in 10 countries. Of 10,007 articles, 86 percent were devoted exclusively to male sports and athletes (Jorgensen, 2005). When women do get newspaper space, it is less likely to be accompanied by 
photographs and 'a substantial proportion of it is actually derogatory or focused excessively on the sportswoman's physical appearance' (Donohoe, 2003, p. 4). Women's sports registered just 6.3 percent of airtime compared with 91.4 percent for men on television sports news and highlights shows in the United States between 1989 and 2004 (M. C. Smith, 2005). 'There is a continuing marginalisation, or downright ignoring, of women's sports by the media,' says Michael Messner (2005, p. 1), co-author of the 'Gender in televised sports' study.

Journalists occasionally answer the critics, although few are as candid as The Press' Tony Smith:

\begin{abstract}
Media sports departments are often bombarded with complaints that coverage of women's sport is ghettoised to postage stamp-sized reports buried in the inside pages or nanosecond sound bites at the rump-end of TV and radio bulletins. In mitigation, New Zealand media outlets are much more generous in reporting women's sport than our misogynistic mates in Australia, Britain and the United States ... But, in general, women's sport does deserve more coverage and kudos in this country (T. Smith, 2005, p. F8)
\end{abstract}

Indeed, studies by those who have researched the sports media suggest thatrather than setting the pace for their international compatriots - not all is rosy in the New Zealand sports media's garden. In 1992, women's coverage in six New Zealand newspapers accounted for 12.4 percent of sports news space, against 75.5 percent for men. By 1996, coverage for female sports in the same six newspapers had dropped 'to only 4.4 percent of the total space devoted to sports news', compared with 79.9 percent for male sports (McGregor \& Fountaine, 1997, p. 40). In 1998, again in the same six newspapers, 11 percent of overall coverage went to women's sports (Fountaine and McGregor, 1999). On average, from 1982 to 2002, everyday sports coverage in the New Zealand press favoured males by a ratio of $8: 1$, with just 10 percent of space devoted to women's sports (Bruce, 2006a).

Studies of Australia's traditional sports media also reveal a pattern of disregard for women's sport (Alston, 1996; Brown, 1995; Mikosza, 1997; Phillips, 2000). However, the body of evidence is incomplete without information on the performance of 'new' media. Rapid growth in internet use from the late 1990s (just over half of Australian households now have an internet 


\section{CONTEMPORARY GENDER ISSUES}

connection, more than 58 percent of adults and 44 percent of children aged 8 to 17 years use the internet) indicates the internet 'is assuming increasing importance as a content and communication resource in Australia' (Australian Bureau of Statistics, 2005a; Netalert, 2005).

One study of Australia's new media (Jones, 2004) reports atypical treatment for sportswomen on News Online, the online arm of the national public broadcaster, the ABC. A content analysis of News Online's coverage of the 2000 Olympics found almost equal coverage for Australian female and male athletes in terms of the number of words written about them.

The number of words devoted to sportswomen is only one gauge of their equitable treatment in sports journalism. Studies of the sports press (Alston, 1996; Kinnick, 1998), sports websites (Sagas, Cunningham, Wigley \& Ashley, 2000; Women's Sports Foundation UK, 2004), and the author's thesis (Jones, 2003) indicate that female athletes are often marginalised or stereotyped in pictorial coverage. Kachgal (2001) says marginalisation occurs when females are under-represented or excluded from visual depictions of their sports contests, while stereotypes are perpetuated through the use of images that represent females in formulaic and overly simplistic terms based on gender - such as images of women competing in so-called 'feminine' sports (Kane, 1996; Lumpkin \& Williams, 1991).

This article examines the images of female and male athletes presented to News Online audiences in coverage of the 2004 Olympic Games to determine whether the depiction of females has improved in frequency or context since the 2000 Games. This research, which replicates the author's content analysis of Olympic sports images in 2000 (Jones, 2003), offers an indication of improvement, regression or maintenance of the status quo in News Online's visual coverage of Australian athletes. The results obtained from the Olympics sample cannot be generalised to News Online's everyday coverage or to that of any other web or traditional sports media. Nor can claims be made about the impact of News Online's Olympic sports content in the absence of a study which examines the audience. It is not the purpose of this study to do so. Rather, results from a content analysis of News Online showing substantial differences in representation for one gender over another-within the timeframe of the 2004 Olympics, and against the results of the 2000 Olympics study — would be important since, as Fountaine and McGregor (1999, p. 115) note, 'comparative research over the years allows for monitoring of trends rather than simply providing a snapshot approach to news content'.

110 PACIFIC JOURNALISM REVIEW 12 (1) 2006 
While the results of this study could reflect on News Online's performance against the ABC's policy of balance in news coverage, they could also lend support to the idea that new media have the potential to present a new view of sportswomen and sportsmen to their audiences. The internet has unique characteristics which include: asynchronous message delivery and consumption (users can consume media at their leisure); non-linearity (users can access information in sequences they determine); non-hierarchical organisation (senders and receivers have comparatively equal status); dynamism (form and content are always changing); and interactivity (users can affect the output of information) (Kachgal, 2001). According to some researchers, these dissimilarities with traditional media might make it possible to 'rupture strategies for representing gender' (since the web's unique qualities make it potentially more inclusive and empowering for women). Other scholars have argued that 'communications innovations have historically led to the consolidation of power by dominant groups', thus reinforcing patriarchal ideology (Kachgal, 2001, p. 173).

Information about the amount and nature of sports coverage on $\mathrm{ABC}$ News Online is important given the corporation's distinctive place in Australia's media landscape. Under the Australian Broadcasting Corporation Act 1983, the ABC's responsibilities include the provision of an independent, comprehensive and non-discriminatory news service (Australian Broadcasting Corporation, 2002) to listeners and viewers whose numbers include a growing internet audience (the ABC's website is in the top 10 Australian sites, and its News and Current Affairs sites recorded 4.2 million average weekly accesses in 2004-05) (Australian Broadcasting Corporation, 2005).

Despite millions of dollars in Government funding for sports programmes, facilities, administration and coaching, the gap in sports participation rates in Australia has blown out by more than 10 percentage points in favour of males (Australian Bureau of Statistics, 2003). So, it is timely to examine online sports journalism on Australia's public broadcaster in light of two main principles concerning the media's role. The first maintains that the mass media is 'one of the most powerful institutional forces for shaping values and attitudes in modern culture' (Duncan, 1990; Sagas et al., 2000). In doing so, it influences public perceptions about appropriate, normal and reasonable behaviour (Robertson, 1997), and provides role models for female youth to emulate (Rintala \& Birrell, 1984). 


\section{CONTEMPORARY GENDER ISSUES}

The second asserts that ignoring women's sport sends a message to many sections of the community that women's sport is unimportant and unworthy of attention (Toohey, 1997). Gender representation in sports coverage is subject to 'the increased commercial imperatives driving media sport' (McGregor \& Fountaine, 1997, p. 38). Professional male sports which create the biggest turnovers in advertising, sponsorship, numbers of television viewers and spectators in the stadium dominated the international sports press in 2005. Just 1 percent of newspaper space dealt with amateur and recreational sports (Jorgensen, 2005). In the New Zealand press, 'the globalisation, commodification and professionalisation of sport' have marginalised women's sports and amateur men's sports to the extent that the bulk of the sports pages are taken up by 'more and more rugby league, rugby union, international soccer and other strange sports that New Zealanders don't participate in' (Bruce, 2006b). These factors then serve 'to reinforce and legitimise the patriarchal male sport model as hegemonic' (Toohey, 1997, p. 21).

\section{Literature review}

Photographic profiles in the sports media

When readers turn to the sports section of their newspaper, they are more likely to see a picture of a male athlete (Bryant, 1980; Duncan, Messner, \& Williams, 1990; George, Hartley \& Paris, 2001). Photographic profiles for women rarely reflect their participation in sport (Alston, 1996; Flatten \& Matheson, 1996) and often fall well below half the number of photographs devoted to men and men's sports (Hardin, Lynn, Walsdorf, \& Hardin, 2002; Hollinshead, 2001).

Despite the introduction in 1972 of Title IX anti-discrimination laws in the United States, more than 20 years later female athletes were under-represented in university-sponsored newspapers, receiving 36 percent of photographs against their student population of 49 percent (Wann, Schrader, Allison, \& McGeorge, 1998), and on NCAA-sponsored sports websites where more than half of all baseball reports included photographs of players but less than one third of softball stories were accompanied by photographs (Sagas et al., 2000). Gniazdowski and Denham (2003) found only 6 percent of photographs in the leading sports magazine, Sports Illustrated, were of female athletes while its stablemate, Sports Illustrated for Kids, also favoured male athletes by featuring them in 76 percent of photographs (Hardin, Lynn et al., 2002). 
Australian capital city dailies' male bias in their choice of sports pictures has seen the publication of 12 times as many photographs of men's sports than of women's sports, with women receiving only 7.5 percent of all sports pictures (Menzies, 1989). In British broadsheets, the margin is as much as 17:1 in favour of male photographs, and in US newspapers men have received 13 times as many photographs as women (Duncan et al., 1990).

Images on commercial online media sites too have highlighted male athletes. In Kachgal's study of three leading US sports websites, men registered 86 percent of pictures. The fewer pictures of women (22 out of 162) meant more news items about females contained no images of them (Kachgal, 2001). A similar finding was reported by the UK Women's Sports Foundation (2004) in its investigation into coverage of women's sport on the BBC sport website. Pictures of women were far more likely to be used to illustrate the site's fun and games section. Of 88 pictures on the public broadcaster's 'Pic of the day' page, nine (10 percent) depicted female athletes, none of whom were UK athletes.

Every four years spikes can occur in female sports coverage. Bruce (2006b) says a 'significant change' occurs in the New Zealand press' focus when major events are underway. Female athletes received 66 percent of newspaper space against 34 percent for males during the 2002 Commonwealth Games, and 27 percent of space compared with 45 percent for males during the 2004 Olympic Games.

Vincent's cross-national study of 1996 Olympics reporting found females received 43 percent of all photographs in six US, UK and Canadian newspapers (Vincent, Imwold, Masemann \& Johnson, 2002). Hardin reported a similar result in her evaluation of coverage of the 2000 Olympics in five US newspapers. The overall proportion of photographs for women and men differed by four percentage points ( 52 percent for men, 48 percent for women), and compared favourably with demographics for the US Olympic team (55 percent males, 45 percent females) (Hardin, Chance, Dodd \& Hardin, 2002). While men dominated 2000 Olympics pictures on News Online, the 38 percent of pictures devoted to women matched their medal success at the Games (Jones, 2003).

Media images have traditionally shown athletes competing in individual rather than team sports (Tuggle \& Owen, 1999). This was again the case with NBC's telecast and US newspaper coverage of the 2000 Olympics where 


\section{CONTEMPORARY GENDER ISSUES}

individual women's competitions received almost six more hours of airtime than team competitions (Hardin, Chance et al., 2002; Tuggle, Huffman \& Rosengard, 2002), and more press pictures respectively. However, compared with the US Olympic team's demographics ( 45 percent females, and 55 percent males), women received favourable newspaper pictorial coverage (48 percent of images). Women's team sports, too, were well represented and were more likely to appear in an Olympic photo than were men's teams. This reflects, arguably, the greater number of team sports available to women in Sydney, or the US team medal count. US women's teams won more gold medals than did men's teams during the Games (Hardin, Chance et al., 2002).

Playing with images of female athletes

Publishing fewer pictures of female athletes is one example of overt discrimination in sports coverage. What is depicted in these images also matters. Photographic images tell stories. '[They] are so much a part of our daily lives we rarely think about how they influence us and what that influence is' (Duncan, 1990, p.22). Duncan argues that sports photographs are politically motivated. In portrayals of the human body, hegemonic groups use the naturalness of photographs to legitimate their own interests, so photos serve to shape consensus or consent to existing social arrangements. Their message gets passed off as objective and unmotivated at the same time as it serves some interests more than others.

According to Duncan (1990), the content or discourse of the photographs can suggest 'otherness' when there is an excessive focus on:

(a) women's physical appearance (the most glamorous female athletes are pictured most often)

(b) poses with sexual connotations (showing 'forbidden' sights, resembling soft-core pornography)

(c) emotional displays (where pictures are predominantly of tearful female athletes), and

(d) sexual difference (portrayals of women as passive participants in sports and men as active competitors).

Several studies support Duncan's assertion of heavy gender bias in sports photographs. The most frequently pictured females in Sports Illustrated were in sex-appropriate sports (ice skating and gymnastics), accentuating the traditional definition of femininity (Lumpkin \& Williams, 1991). Hardin et al 
(2002) reported the perpetuation of sexual difference through portrayals of women as passive participants in sports considered 'feminine'. George et al (2001) found the British media gave preference to male action shots (78 percent of male photographs) over female action shots ( 52 percent), and females were twice as likely as males to be shown in passive shots. In contrast, there was little evidence of bias in newspaper pictures of 1996 Olympic athletes. Females were more likely to be depicted engaging in sport than males (58.4 percent of images vs 52.7 percent), and slightly less likely to be depicted in passive positions (Kinnick, 1998).

\section{Research questions}

This study builds on the author's previous research examining ABC News Online's pictorial coverage of Australian female athletes at the 2000 Olympic Games. The primary question is: Has there been any change in the number and nature of images published on News Online during the 2004 Athens Olympics or did photographic coverage reflect the differential treatment accorded Australian female and male athletes on the website in 2000? Results from the 2000 study (Jones, 2003) provided a baseline for comparison, and an indication of whether the 2004 data represented regression, maintenance of the status quo, or improvement in News Online's performance.

The following questions guided data collection, categorisation and analysis:

1. What was the level of coverage in pictures given to Australian female and male athletes?

2. Did picture placement with the lead report on the website's splash page (also known as Tier One [T1]) give one gender more prominence than the other?

3. Did pictures frame female athletes as passive rather than active subjects?

4. Were females depicted more often competing in so-called 'appropriate' sports than in 'inappropriate' sports?

5. Did the level of coverage (identified in 1) correlate with the number of medals won by Australian female and male athletes?

6 . Did the level of coverage (identified in 1) accurately reflect the gender composition of the Australian Olympic team? 


\section{CONTEMPORARY GENDER ISSUES}

\section{Method}

\section{Data collection and definitions}

The website http://abc.net.au/olympics/default.htm was the sampling unit for this study. While the sample period of the Olympic Games is pre-determined, different time zones and peak viewing times for News Online (Alysen, 2000) were considered when designing the sampling plan. The splash pages and Tier Two (T2) reports linked to them from 19 Olympic bulletins, posted from 12-30 August 2004 and downloaded daily between $8 \mathrm{am}$ and $10 \mathrm{am}$ or $8 \mathrm{pm}$ and $11 \mathrm{pm}$, were examined.

Sports pictures were defined as those images featuring Australian Olympic athletes and illustrating stories whose topics or themes were sports contests, achievements, or issues affecting those Olympians. For example, a picture of an Australian athlete accompanying a story about the athlete's medal chances was eligible since the story was a preview or speculator about competition.

Pictures in splash page summaries and side bars, and Tier Two (T2) stories - showing one or more Australian athletes, and irrespective of whether they were photographed with athletes of other nations - were categorised and counted according to the gender of the featured Australian athlete. When Australian athletes of both genders were shown together, the picture was categorised as one image for each gender. The number of athletes appearing in a picture was not counted. The traditional, print-prominence measure of picture size was discounted, as there was no apparent connection between size and orientation and the accompanying story's position within the bulletin. Graphics were not counted.

All pictures of Australian athletes were examined according to gender for depictions of passive or active poses. Subjects were defined as passive or doing nothing if they were motionless (for example, recovering after exertion), appeared only from the neck up (mug shots), were clearly posing for the camera, or appeared celebrating rather than actively competing in their sport. Active subjects were clearly doing something; that is, they were shown competing in or about to compete in their sport (for example, taking aim at a target, or on the starting blocks).

Pictures were also examined for depictions by gender of athletes competing in female-appropriate, male-appropriate and gender-neutral sports. Female-appropriate sports (such as gymnastics and diving) emphasise aesthet- 
ics and beauty but discourage physicality. Male-appropriate sports (such as basketball, hockey and water polo) emphasise physical strength or power, stamina and contact through active, aggressive and autonomous behaviour. Shooting and volleyball are seen as neutral sports (Daddario, 1998; Jones, Murrell \& Jackson, 1999).

Content analysis, coding, reliability and data analysis

Content analysis, commonly used to discover and describe the quantitative content of the mass media's messages in an objective and systematic way (Frey, Botan, Friedman, \& Kreps, 1992) and 'determined as an effective way to examine media images of minority or historically oppressed groups' (Hardin, Lynn et al., 2002, p. 348), was used to address the research questions. The problem of checking inter- and intracoder reliability for changing content on the website (McMillan, 2000) was answered by old technology. To ensure that coders would be cross-coding faithful and identical data, hard copies were printed of the context units - each daily bulletin's splash page and the $\mathrm{T} 2$ reports accessed by hyperlink from the splash page.

A trained coder and the author independently coded a sub-sample of 10 odd number bulletins (out of 19). Intercoder reliability was assessed using Holsti's formula (Wimmer \& Dominick, 2000) with results ranging from .85 to 1.00 in the categories of splash page lead report pictures, T1 side bar pictures, $\mathrm{T} 2$ report pictures, and active or passive depictions of females. Intracoder reliability, established by comparing coding sheets on identical data completed by the author one week apart, was 1.00 for active and passive depictions of male athletes. Overall reliability was .95 .

Total measures according to gender were calculated for the independent variables of lead, side bar and T2 report pictures, picture placement, picture context, and sex-type of sport. These measures were converted to frequencies and subjected to chi-square or Kruskal Wallis $\mathrm{H}$ analysis. The frequencies for pictures of female and male athletes were also compared with two 'representation' indices. First, the percentage of medals won by each gender was subtracted from each gender's percentage of coverage to compute a coverage-tomedals representation index. Next, the method was repeated-with the percentage of female and male athletes in the national team replacing the percentage of medals won in the above calculation - to produce a coverage-toteam population index. 


\section{CONTEMPORARY GENDER ISSUES}

\section{Results}

Females outnumbered males in News Online pictures. Sportswomen were depicted in 53 percent of the 150 pictures accompanying sports stories on the splash and T1 side bar and T2 pages, a finding in contrast with the author's 2000 Olympics study (2003) where 38 percent of pictures were given to females (see Table 1). ${ }^{1}$

Lead story pictures on the site's splash page were twice as likely to depict female athletes than male athletes. Almost 65 percent of pictures illustrating lead stories depicted sportswomen, a finding that is in contrast with the author's 2000 study (2003) where male athletes received 56 percent of lead story pictures (see Table 1$)^{2}{ }^{2}$

Sportswomen were also portrayed in action more often than in passive poses, and more often in active poses than male athletes. While images of active athletes comprised 60 percent of female pictures, the proportion of active depictions fell from the 69 percent registered in the author's Sydney Olympics study (2003), where females were twice as likely to be shown in action than doing nothing (see Table 2). ${ }^{3}$

Frequencies for pictures of sportswomen showed a clear margin in favour of depictions of male-appropriate sports (64 percent or 51 of 79 pictures) compared with 28 percent for female-appropriate and 8 percent for neutral sports. ${ }^{4}$ In contrast to frequencies, the mean ranks for appropriateness suggest neutral sports received the highest coverage score (8.5), with the lowest score (7.87) reported for female-appropriate sports. This finding echoes the author's Sydney Olympics study (2003) when neutral sports also received the highest coverage score.

Male-appropriate sports also topped the frequencies for depictions of men ( 37 pictures or 54 percent of male pictures), with 32 per cent of pictures showing female-appropriate sports and 14 percent devoted to neutral sports. ${ }^{5}$ Contrary to the author's 2000 study (2003) where neutral sports received the highest mean rank for appropriateness, in 2004 male-appropriate sports received the highest coverage score (7.88), ahead of neutral (7.16) and femaleappropriate sports (6.83).

Australia won 49 medals at the 2004 Olympics. Of these, 23 (47 percent) went to females who received 53 percent of pictures. Male athletes, who won 26 medals (53 percent), received 70 pictures. Female athletes accounted for 43 percent of the 482 athletes in the 2004 Australian Olympic team, and males

118 PACIFIC JOURNALISM REVIEW 12 (1) 2006 
CONTEMPORARY GENDER ISSUES

comprised 57 percent. Tables 3 and 4 report the coverage received by each gender compared with their Games performances and their team population.

\section{Discussion}

The findings in this study of pictorial representation of Australian Olympians on News Online indicate a major departure from the results obtained by the author in 2000 . The 2004 content analysis suggests the erosion of male dominance and, in the frequency of pictures, relatively equal treatment for athletes

\begin{tabular}{|c|c|c|c|c|c|c|}
\hline \multirow[b]{2}{*}{ Pictures* } & \multicolumn{2}{|c|}{ Female } & \multicolumn{2}{|c|}{ Male } & \multicolumn{2}{|c|}{ Total } \\
\hline & $\mathbf{n}$ & $\%$ & $\mathbf{n}$ & $\%$ & $\mathbf{n}$ & $\%$ \\
\hline Splash lead (T1) & 11 & 7 & 6 & 4 & 17 & 11 \\
\hline Side bar (T1) & 15 & 10 & 11 & 7 & 26 & 17 \\
\hline Story (T2) & 54 & 36 & 53 & 36 & 107 & 72 \\
\hline Total & 80 & 53 & 70 & 47 & 150 & 100 \\
\hline
\end{tabular}

Percentages have been rounded off

Table 2: Depictions of active and passive athletes by gender on ABC News Online

\begin{tabular}{lllllll|} 
& \multicolumn{2}{c}{ Female } & \multicolumn{2}{c|}{ Male } & \multicolumn{2}{c|}{ Total } \\
Picture context & $\mathbf{n}$ & $\mathbf{\%}$ & $\mathbf{n}$ & $\%$ & $\mathbf{n}$ & $\%$ \\
Active & 48 & 32 & 32 & 21 & 80 & 53 \\
Passive & 32 & 21 & 38 & 26 & 70 & 47 \\
Total & $\mathbf{8 0}$ & $\mathbf{5 3}$ & $\mathbf{7 0}$ & $\mathbf{4 7}$ & $\mathbf{1 5 0}$ & $\mathbf{1 0 0}$ \\
\hline
\end{tabular}

Percentages have been rounded off

Table 3: Coverage-to-medals won as a representation index *

\begin{tabular}{llll} 
Gender & $\%$ of pictures & $\%$ of medals & Rep. index \\
Female & 53 & 47 & +6 \\
Male & 47 & 53 & -6 \\
Total & 100 & 100 & \\
Total pictures & 150 & & \\
\hline
\end{tabular}

${ }^{*}$ ABC News Online 
CONTEMPORARY GENDER ISSUES

Table 4: Coverage-to-team population as a representative for Australian athletes *

$\begin{array}{llll}\text { Gender } & \% \text { of pictures } & \% \text { of team } & \text { Rep. index } \\ \text { Female } & 53 & 43 & +10 \\ \text { Male } & 47 & 57 & -10 \\ \text { Total } & 100 & 100 & \\ & & & \end{array}$

${ }^{*} \mathrm{ABC}$ News Online

of each gender. But the greater number of images for women came with a twist: it was more common to find a picture of a woman who lost than a man who lost.

From under-representation in 2000, females rebounded to register more pictures than males in all three locations on the site - splash page lead stories, splash page side bars and T2 main reports linked to the splash pageand more pictures than their Olympic team demographic would seem to warrant. The most dramatic turnaround occurred in depictions accompanying T2 stories where the number of images of females increased by 125 percent on the 24 pictures recorded in 2000 .

How a knee inflated female coverage

One explanation for the improved showing of females in pictures is that this exposure was sensitive to outstanding achievements. Women took a greater share of Australia's medal haul in Athens (47 percent) than in Sydney (38 percent), but not all Australian medal successes were reported in the sampled bulletins and a high proportion of $\mathrm{T} 2$ stories on News Online were not accompanied by pictures.

Part of the answer more likely lies in the disproportionate treatment of one or more athletes whose stories were illustrated by one or more pictures. In this respect, depictions of females on News Online echo a finding of the 2000 Olympics study when one third of 35 female images on the website were devoted to Cathy Freeman (2003). As a gold medallist, Freeman was entitled to recognition. Yet no other Australian, gold medallist or not, in any sport, received the attention afforded Freeman. While her Olympic campaign and success as the first Aborigine to win an individual Olympic gold medal embodied elements of the newsmaking process - and satisfied several news 
values - an examination of race and its influence on coverage was not within the scope of either of the author's Olympic studies.

In 2004, it was the turn of hurdler Jana Pittman to eclipse Freeman's tally and inflate pictorial coverage for women. Pittman's knee injury, rather than a medal of any colour, saw her feature in 17 pictures spread across 13 bulletins and account for one fifth of female pictorial coverage. In contrast, Australia's most successful male competitor at Athens, Ian Thorpe (two gold, one silver and one bronze medal), received 10 individual pictures and one group shot, or 14 percent of all male images. Pittman and Thorpe were the only athletes to reach double figures in images. Swimmer Jodie Henry (six pictures, one individual and two relay gold medals) and basketballer Lauren Jackson (six pictures, one team silver medal) were the next best performers in coverage for women, while Grant Hackett (one gold and two silver medals) was seen in six individual pictures and one group shot. Pittman's impact on female pictorial coverage is most graphic when her quota is removed from the tally for women. Without the 17 images devoted to Pittman, women's share of pictures on News Online drops to 63 or 47 per cent of all pictures on the site (see Graph 1).

\section{A select few made it above the fold}

Sportswomen outnumbered men by a ratio of 2:1 in the most prominent position on the Olympics site, the splash page lead story. This prime location, akin to above the fold on a newspaper's front page and usually out of bounds

\section{Graph 1: Female pictures by frequency and the effect of the Pittman factor}

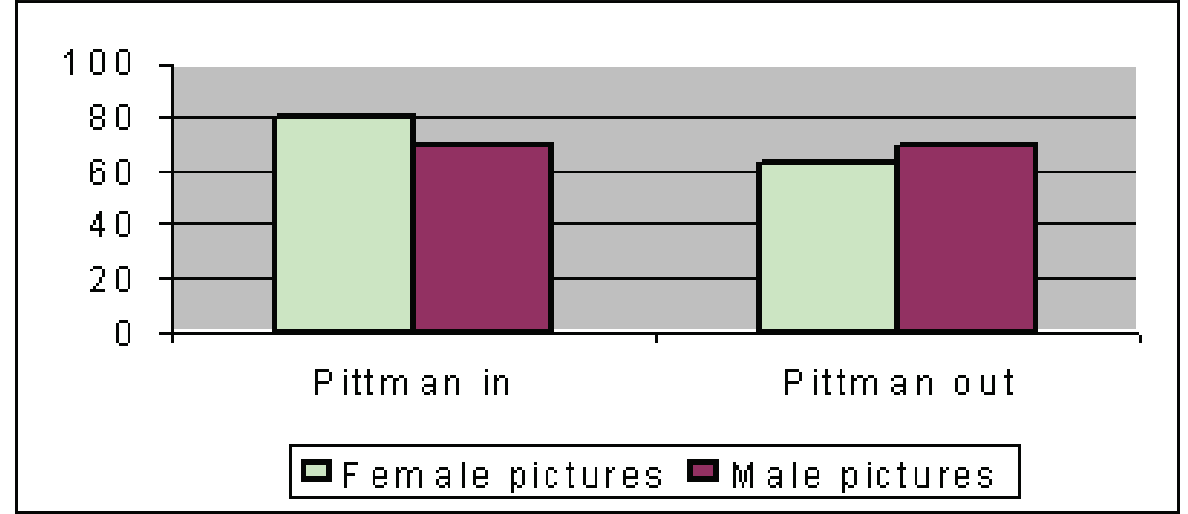




\section{CONTEMPORARY GENDER ISSUES}

for sportswomen (Women's Sports Foundation UK, 2004), went to female images 11 times across 19 bulletins. Yet only five images depicted female medallists when Australian women won eight gold medals alone. Four lead pictures were shared by two non-medallists. Pittman achieved notoriety and three lead images through injury. Rower Sally Robbins collapsed and shot to prominence, even though her story was two days old when she was the subject of a lead picture on August 22. The focus on Robbins (with the news values of failure, conflict and controversy) reflects an otherwise slow day for Australia at the Games.

The online news cycle is a hungry beast. Taking into account the demand for fresh news on a site with a high rotation of bulletins and Pittman's apparent willingness to keep the media apprised daily of her progress towards race fitness, the decision to give her top billing on more than one occasion during the Games remains questionable. As an example, on August 15 News Online led with a picture of Pittman and speculation about her chances of running in the $400 \mathrm{~m}$ hurdles, in over a week's time, after her 'stunning recovery from knee surgery'. On the same day, Australia's women's $4 \times 100 \mathrm{~m}$ freestyle relay team won gold, broke the world record, ended a 48-year drought in the event, registered Australia's only medal win for the day and was relegated to eighth in the bulletin.

In contrast with the coverage afforded women, the number of male pictures on News Online fell by more than 37 percent on the findings in 2000. The most dramatic drop occurred in lead pictures, where men registered less than half of the total for 2000. Unlike female images from Athens, no one male athlete was favoured. Male images depicted a range of athletes from four different sports. They included individuals and teams, medallists and non-medallists.

\section{Women in action}

Active female competitors were seen in more bulletins and in far greater numbers than in 2000 or in previous studies (Alston, 1996; George et al., 2001). Only two bulletins in the 2004 sample failed to deliver at least one active depiction of a sportswoman. The most featured female sport, athletics, registered 13 images of active women from a total of 20 images. Closer inspection, though, again reveals the impact of the Pittman factor. She dominated athletics coverage receiving 17 images. Australia's sole female athletics med- 
allist, Jane Saville, who won bronze in the $20 \mathrm{~km}$ walk, appeared in one image only, not as a competitor but as a passive spectator and in a group shot with two other athletes. While all coverage of Australia's silver medal winning basketballers, the Opals, featured action shots, two thirds of the 12-member team's pictorial coverage went to one player, Lauren Jackson - an outcome, it could be argued, that reflects her participation and profile in the WNBA in the United States.

Action shots accounted for 60 percent of cycling coverage for females on News Online. Unlike athletics and basketball, all three female cyclists (who between them won two gold, one silver and one bronze medal) were represented in images on the site. Yet when $500 \mathrm{~m}$ time trial gold medallist Anna Meares' picture led the bulletin on August 21, she was shown passively wiping a tear from her cheek during the medal ceremony. Duncan (1990) argues such stereotypical portrayals, highlighting an emotional display, trivialise women's athletic performances. In Meares' case, the teary-eyed woman pictured on the dais gives no hint of her stature in a sport that demands mental strength, tactical savvy, aggression, speed, endurance and explosive physical power.

Appropriate sports, stereotypes and exclusion

Depictions of women in neutral sports, which received the highest coverage score for appropriateness, were five times more likely to represent females as active competitors than passive participants. All three images of gold medal shooter Suzanne Balogh, including one that led the bulletin on August 16, profiled the intense concentration of an athlete, her index finger caressing the trigger, poised to fire at an unseen target.

Proportionately, male-appropriate sports accounted for two thirds of female sports pictures and, in this category, stereotypes were perpetuated. Traditionally, women competing in team sports have been under-represented or ignored in sports photographs (Tuggle \& Owen, 1999). In 2004, women competing in male-appropriate individual sports were three times more likely to be shown in images than women competing in team sports. In addition, closeups or medium shots of Opals player Lauren Jackson dominated nine depictions of basketball, the most-featured male-appropriate team sport, as though Jackson was the only member of the Australian team on the court at any time. Such exclusive representation suggests female team sports - as the literature 


\section{CONTEMPORARY GENDER ISSUES}

indicates - are not yet accepted as legitimate contests worthy of whole of team coverage. The result is also striking since, in Australia, more females play team contact sports than individual, non-contact sports (Australian $\mathrm{Bu}$ reau of Statistics, 2005b).

There were disparities in depictions of men competing in team sports. In male-appropriate sports, the most represented sports by frequency and mean rank, pictures of team sports were outnumbered by a ratio of $2: 1$ in favour of images of individual sports. This contrasts with previous studies where team sports dominate male pictures (Alston, 1996; Hardin, Chance et al., 2002). However, pictures of the most photographed men's team, the Kookaburras, were equally divided between passive and action shots of the hockey players and four of six images depicted two or more players, in contrast to the 'individualised' portrayal of the Opals basketball team.

\section{Conclusion}

Aside from two weeks every four years, coverage of women's sport either flatlines or is only a small fraction of that allocated to male athletes. Kinnick's 1996 Olympics study and Hardin et al's 2000 study suggest newspaper portrayals of female Olympians have progressed from stereotypical coverage. In tune with the greater number of women competing at the Olympic Games, the press published more images of women (Hardin, Chance et al., 2002; Kinnick, 1998). Not so the broadcast and online media. In 1996 and 2000, Olympic sportswomen received proportionately less coverage and females competing in team sports were overlooked in favour of individual athletes (Jones, 2003; Tuggle et al., 2002; Tuggle \& Owen, 1999).

This research - which examined the number and nature of images of Australian female and male Olympians on ABC News Online in 2004, and compared their frequency with medal results, team demographics and coverage in 2000 - suggests an increase in the amount of women's sports coverage on News Online. Images of female athletes were in the ascendancy by overall frequency and prominence on the website's prime location, the splash page. Australia's women received more coverage than their medal wins and team population would seem to warrant. However, more coverage in 2004 does not equate to a fairer deal when:

- women were more often depicted as losers than were men

- a focus on one athlete boosted the number of female images by 20 percent

124 PACIFIC JOURNALISM REVIEW 12 (1) 2006 
- compared with News Online's coverage in 2000, the number of passive depictions of women rose by 191 percent, more than twice the increase recorded in passive depictions in the same period for male athletes

- wide angle views of female teams were overlooked in favour of portraits which highlighted the individual 'face' of a team.

The marginalisation (detected in 2000) of some female athletes, especially those who play team sports, continued in 2004 and stereotypes were perpetuated through portrayals of women as tearful, passive participants. Such depictions devalue women's accomplishments and may give credence to sexist notions that women 'can't cut it' in sport because they are physically and emotionally more delicate and less competitive and aggressive than men. They may instill or reinforce in News Online's audiences the stereotypical belief that women's sports are less powerful, less interesting and thus separate and different from men's sports. Such conjecture needs detailed audience research to be tested properly.

Such depictions also contravene the $\mathrm{ABC}$ 's guidelines for news presentation which demand accurate, impartial and objective journalism. Fair reporting does not mean 'merely an endorsement of the status quo' (Australian Broadcasting Corporation, 2002, pp. 18-19). ABC journalists are required to treat all sections of society with respect and to avoid the use of prejudicial language and images. Images are prejudicial if they disparage or discriminate against any person (on grounds including gender); are not representative and reinforce stereotypes, or convey stereotypical assumptions about gender roles; convey prejudice; or make demeaning or gratuitous references (Australian Broadcasting Corporation, 2002).

Journalists have a defence. If the material is factual, it can be published. The passive images of female athletes published on News Online were factual and framed them reacting to success, receiving medals, leaving the competition arena, and spectating. However, only one quarter of the images of female gold medallists published on the site's prime location - the splash page - showed these women in action in power sports such as cycling or precision sports such as diving. None of the 11 images of Australia's successful women swimmers, including one splash page picture of the $4 \times 100 \mathrm{~m}$ relay team on August 22, showed them in action, powering through the water to win their seven individual and two relay medals.

Studies of the coverage of two successive Olympics on News Online be- 


\section{CONTEMPORARY GENDER ISSUES}

gin to provide the framework for a longitudinal study of elite sports reporting on the ABC's website. How the ABC performs over a 12-year period (including the 2008 Beijing Games) and against its own standards for reporting matters, since: 'Who and what is covered at the Olympics is particularly important in regard to women in sports, because many of those athletes and sports in which they participate receive little coverage beyond Olympic competition' (Tuggle et al., 2002). Future research could also examine, for comparison with the ABC's performance, Olympics coverage on the website of another well known public broadcaster, the BBC. An audit of sportswomen's representation on bbc.co.uk would indicate whether its performance reflects the trend in other UK media which gives female athletes, on average, just 5 percent of sports coverage.

\section{Notes}

1 Chi-square analysis showed the difference between images of female and male athletes in 2004 was not statistically significant, $\mathrm{X} 2(1)=0.667, \mathrm{p}=0.414$.

2 The difference in prominence or placement between images of female and male athletes in 2004 was not statistically significant, $\mathrm{X} 2(1)=1.471, \mathrm{p}=0.225$.

3 The differences between active and passive images of females in 2004, X2(1)= $3.2, p=0.074$, and active and passive depictions of males, $\mathrm{X} 2(1)=0.514, \mathrm{p}=0.473$, were not statistically significant.

4 Kruskal Wallis $\mathrm{H}$ analysis reveals that the number of pictures of females was not statistically equal with regard to appropriateness, $\mathrm{H}=6.02$, X2 .05(2) $=5.99$.

5 The number of pictures of males was not statistically equal with regard to appropriateness, $\mathrm{H}=6.16, \mathrm{X} 2.05(2)=5.99$.

\section{References}

Alston, M. (1996). Goals for women: Improving media representation of women's sport. Wagga Wagga: Centre for Rural Social Research, Charles Sturt University. Alysen, B. (2000). The electronic reporter: Broadcast journalism in Australia. Geelong: Deakin University Press.

Australian Broadcasting Corporation (2002). Editorial policies. (Retrieved July 2004). http://abc.net.au/corp/edpol02.pdf

Australian Broadcasting Corporation (2005). Annual report 2004-05. (Retrieved December 2005). www.abs.gov.au

Australian Bureau of Statistics (2003). Sport and recreation: A statistical overview. (Retrieved June 2004). www.ausstats.abs.gov.au/ausstats/subscriber.nsf/Lookup/ 10A5225E891BE3A5CA256DDD007D5523/\$File/41560_2003.pdf.

Australian Bureau of Statistics (2005a). Home internet use continues to rise, Australian Bureau of Statistics. (Retrieved December 2005). www.abs.gov.au

126 PACIFIC JOURNALISM REVIEW 12 (1) 2006 
CONTEMPORARY GENDER ISSUES

Australian Bureau of Statistics (2005b). Participation in sports and physical activities 1301.0. (Retrieved December 2005).www.abs.gov.au/Ausstats/abs@nsf/ 94713 a d $445 \mathrm{fff} 1425 \mathrm{c}$ a 2568220000192 a f $2 /$ daaada81176e2f89ca256f7200833023!OpenDocument

Brown, P. (1995). Gender, the press and history: Coverage of women's sport in the Newcastle Herald, 1890-1990. Media Information Australia 75(February). pp. 24-34.

Bruce, T. (2006a). Interrogating the intersections of nationalism and gender in media coverage of international sports spectacles: the case of the Commonwealth and Olympic Games. Paper presented at the International Sports Studies Conference, Victoria University, Melbourne, March 6-8.

Bruce, T. (2006b). Personal communication with author.

Bryant, J. (1980). A two-year selective investigation of the female in sport as reported in the paper media. Arena Review 4. pp. 32-44.

Daddario, G. (1998). Women's sport and spectacle: Gendered television coverage and the Olympic Games. Westport: Praeger.

Donohoe, H. (2003). Britain's best kept secrets. Women's Sports Foundation UK. (Retrieved September 2005). Www.ews-online.org/ index.php?do $=100213006 \& 1 \mathrm{a}=2 \& \mathrm{~kat}=316$

Duncan, M. C. (1990). Sports photographs and sexual difference: Images of women and men in the 1984 and 1988 Olympic Games. Sociology of Sport Journal 7(1). pp. 22-43.

Duncan, M. C., M. Messner, et al. (1990). Coverage of women's sports in four daily newspapers, Amateur Athletics Foundation of Los Angeles. (Retrieved August 2001). www.aafla.com/9arr/ResearchReports/ResearchReport1_htm

Flatten, K. and H. Matheson (1996). Newspaper representation of women athletes in 1984 and 1994, Women in Sport and Physical Activity Journal: 1-12.

Fountaine, S., \& J. McGregor (1999). The loneliness of the long distance gender researcher: Are journalists right about the coverage of women's sport? Australian Journalism Review, 21(3), 113-126.

Frey, L. R., C. H. Botan, et al. (1992). Interpreting communication research. Englewood Cliffs: Prentice-Hall.

George, C., A. Hartley, et al. (2001). The representation of female athletes in textual and visual media. Corporate Communications: An International Journal 6(2). pp. 94-101.

Gniazdowski, L. A. and B. E. Denham (2003). Still photographs of female athletes featured in Sports Illustrated versus Sports Illustrated for Women, Association for Education in Journalism and Mass Communication. (Retrieved July 2004). http:// list.msu.edu/cgi-bin/wa?A2=ind0310a\&L=aejmc $\& D=O \& P=8561$

Hardin, M., J. Chance, et al. (2002). Olympic Photo Coverage Fair to Female Athletes. Newspaper Research Journal 23(2, 3). pp. 64-78.

Hardin, M., S. Lynn, et al. (2002). The framing of sexual difference in SI for Kids editorial photos. Mass Communication and Society 5(3). pp. 341-359. 


\section{CONTEMPORARY GENDER ISSUES}

Hollinshead, R. (2001). The effects of sports information on gender equity in the media, AVCA. (Retrieved October 2005). www.avca.org/news/SIDstory-NW7-2501.html

Jones, D. (2003). Half the Story? Olympic Women on ABC News Online. Unpublished MA thesis. Wollongong: University of Wollongong.

Jones, D. (2004). Half the story? Olympic women on ABC News Online. Media International Australia February (110). pp. 132-146.

Jones, R., A. J. Murrell, et al. (1999). Pretty versus powerful in the sports pages, Journal of Sport and Social Issues: 1-8.

Jorgensen, S. S. (2005). The world's best advertising agency: the sports press, Mandagmorgen. (Retrieved December 2005). www.clubedejournalistas.pt/Portals/ 57ad7180-c5e7-49f5-b282-c6475cdb7ee7/sport_press_survey_english.pdf

Kachgal, T. M. (2001). Home court disadvantage? Examining the coverage of female athletes on leading sports websites: A pilot study. National Convention of the Association for Education in Journalism and Mass Communication, Washington, DC.

Kane, M. J. (1996). Media coverage of the post Title IX female athlete: A feminist analysis of sport, gender and power. Duke Journal of Gender Law and Policy 3(1). pp. 95-127.

Kinnick, K. N. (1998). Gender bias in newspaper profiles of 1996 Olympic athletes: A content analysis of five major dailies. Women's Studies in Communication 21(2). pp. 213-237.

Lumpkin, A. and L. D. Williams (1991). An analysis of Sports Illustrated feature articles, 1954-1987. Sociology of Sport Journal 8(1). pp. 16-30.

McGregor, J., \& Fountaine, S. (1997). Gender equity in retreat: The declining representation of women's sport in the New Zealand print media. Metro, 112, pp. 38-44.

McMillan, S. J. (2000). The microscope and the moving target: The challenge of applying content analysis to the world wide web. Journalism and Mass Communication Quarterly 77(1), pp. 80-98.

Menzies, H. (1989). Women's sport: Treatment by the media. In Dyer, K. (Ed), Sportswomen Towards 2000: A Celebration. Richmond: Hyde Park Press.

Mikosza, J. (1997). Inching forward: Newspaper coverage and portrayal of women's sport in Australia. O'Connor: Womensport Australia.

Netalert (2005). Kids online at home, Netalert. (Retrieved December 2005). http:// www.netalert.net.au/02010-kidsonline@home-Internet-use-in-Australianhomes-April2005.pdf

Phillips, S. (2000). Facts on media coverage for women in sport: An illusory image facts at a glance, SportNet. (Retrieved April 2001). www.sportnet.com.au/home/ content/women/index.cfm

Rintala, J. and S. Birrell (1984). Fair treatment for the active female: A content analysis of Young Athlete magazine. Sociology of Sport Journal 1, pp. 231-250.

Robertson, B. (1997). How do our daughters grow? Adolescent socialisation messages in selected print and electronic media. Chicago, Association for Education in Journalism and Mass Communication.

\section{PACIFIC JOURNALISM REVIEW 12 (1) 2006}


Sagas, M., G. B. Cunningham, et al. (2000). Internet coverage of university softball and baseball websites: The inequity continues. Sociology of Sport Journal 17(2). pp. 198-205.

Smith, M. C. (2005). The battle rages: The sports world seems to be interested in women athletes only when they challenge their male counterparts. The Orange County Register, p. 1.

Smith, T. (2005). NZ women merit more. The Press, p. F8.

Toohey, K. (1997). Australian television, gender and the Olympic Games. International Review for the Sociology of Sport, 32(1), pp. 19-29.

Tuggle, C. A., S. Huffman, et al. (2002). A descriptive analysis of NBC's coverage of the 2000 Summer Olympics. Mass Communication and Society, 5(3). pp. 361-375.

Tuggle, C. A. and A. Owen (1999). A descriptive analysis of NBC's coverage of the Centennial Olympics: 'The Games of the women?' Journal of Sport and Social Issues, 23(2), pp. 171-182.

Vincent, J., C. Imwold, et al. (2002). A comparison of selected 'serious' and 'popular' British, Canadian, and United States newspaper coverage of female and male athletes competing in the Centennial Olympic Games. International Review for the Sociology of Sport, 37(3-4), pp. 319-335.

Wann, D. L., M. P. Schrader, et al. (1998). The inequitable newspaper coverage of men's and women's athletics at small, medium and large universities. Journal of Sport and Social Issues, 22(1), pp. 79-87.

Wimmer, R. D. and J. R. Dominick (2000). Mass media research: An introduction. Belmont, California: Wadsworth Publishing Company.

Women's Sports Foundation UK (2004). An investigation into coverage of women's sport on the BBC sport Website, Women's Sports Foundation. (Retrieved September 2005). www.ews-online.org/index.php?do $=100213006 \& 1 \mathrm{a}=2 \& \mathrm{~kat}=316$

Dianne Jones is a lecturer in journalism in the Faculty of Arts, University of Southern Queensland, Toowoomba, Queensland. She is currently completing a PhD thesis on gender representation in online sports reporting. jonesd@usq.edu.au 